are as essential to organic chemistry as are aliphatic substitution processes. There are, however, other excellent monographs which deal with these subjects, and it is too much to expect of anyone that he should devote the time and energy to discuss the whole of the theoretical background of organic chemistry in equal detail.

Judged as a whole, "Structure and Mechanism in Organic Chemistry" is a classic of scholarship which will for a long time be regarded, in Britain at least, as the authoritative treatise upon theories of heterolytic reactions. It does mention that there are also homolytic reactions, but refrains from any discussion of them. As has been pointed out, it must be recognized that the book advocates a particular point of view; but since this is that of the scientific worker who is primarily an experimentalist it will receive the hearty approval of all who call themselves chemists. Prof. Ingold's admirers have hoped for $a_{0}$ long time that he might eventually be induced to write a book such as this : in its detail and wealth of references it certainly surpasses all expectations, while in regard to its clarity of exposition it is typical of Prof. Ingold at the top of his form.

W. A. WATERS

\section{SCIENCE AND RELIGION}

\section{Natural Religion and Christian Theology} By the Rev. Charles E. Raven. (The Gifford Lectures 1951, First Series : Science and Religion.) Pp. vii + 224. (Cambridge: At the University Press, 1953.) $21 s$. net.

THE first volume of Dr. C. E. Raven's Gifford Lectures contains a survey of the work of the early naturalists, of its relation to other scientific studies and to the general climate of thought. This historical survey is made for a theological purpose. For Dr. Raven, 'natural theology' and 'natural history' are closely linked, as they were for the great John Ray, who said "Divinity is my profession" and made it the scientific study of the organic world. Ray's attitude was characteristic of British men of science of the seventeenth century, but is not so popular now, when many see themselves as techno. crats. His attitude has also been rejected by some theologians, ancient and modern. These theologians of the extreme other-worldly view, and the technocrats, of whom the Marxists are the most consistent, both take the same view of science : the first to condemn, and the second to attribute magical virtues to science. For these theologians the natural world is obscure and unintelligible, if not actually given over to the powers of darkness, and those who profess to study it must do so for greed of gain or from even worse motives. The Marxist, granted his inversion of the criteria of good and evil and the consequent changes in terminology, says the same. Both deny that there is any real natural order or any real natural world to be discovered, much less to excite wonder and admiration. Dr. Raven argues against the theologians that if they were right the doctrine of the Incarnation would be self-contradictory, as would the whole Hebrew tradition about the relation between the creatures and the Creator. $\mathrm{He}$ does not trouble to argue with Marxists or technocrats, but treats the scientific side of the matter historically. This is necessary because so much writing on the history of Western science puts physics, especially experimental physics, in the foreground and all the rest dimly in the background. If you do that you practically accept the Marxist view, for experimental physics creates a world of artefacts and considers the world outside the laboratory, if at all, as analogous to that inside. Fortunately, some physicists are not mere artificers and can see that there is a natural order; otherwise there would be a disastrous split between the sciences.

The attitude of the naturalist is fundamentally religious and æesthetic, and, as Dr. Raven indicates, in all probability the first naturalists in Western Europe were the artists. It is an attitude which in its primitive form comes easily to people living under simple conditions closely linked with earth and sea and sky and the living creatures around them. Dr. Raven points to the excellent observation of Nature to be found in Chapters 38 and 39 of the Book of Job and other parts of the Old Testament. On the other hand-and this is a point he might have made more explicit-this attitude does not come at all easily to unfortunate people whose horizon is confined to the modern industrial urban conglomeration of artefacts.

Valuable features of the book are the tribute to the neglected sixteenth-century naturalist, Conrad Gesner, and to the Cambridge Platonists, who mediated between science and religion during the seventeenth century. Altogether this is a fascinating and illuminating book.

A. D. Ritchie

\section{A REVIEW OF THE PLANT KINGDOM}

Plant Morphology

By Prof. Arthur W. Haupt. (McGraw-Hill Publications in the Botanical Sciences.) Pp. ix +464 . (London: McGraw-Hill Publishing Company, Ltd., 1953.) $64 s$.

WHE title of Prof. Haupt's new book, while 1 admittedly correct, is perhaps rather misleading, and plant taxonomy might have been a more appropriate title. It is a survey of the principal groups of the plant kingdom, all of which are dealt with from the point of view of structure, reproduction and development. It is intended to be used as a twosemester course, supplemented by appropriate practical work, and a good general elementary knowledge of botany is assumed. For students in Britain it should comfortably cover most of the systematic botany needed for a general degree.

The author has ranged widely over the plant kingdom and finds room to include most groups in more, or less, detail. In so doing, some will feel he has thrown his net rather too widely. Some groups, like the Isoetales, Psilotales and Laboulbeniales, or even more, the Acrasieae and Labyrinthuleae, and, perhaps, one or two of the algal groups, might with advantage have been left out. In little more than four hundred pages, of which a good deal of the space is occupied by illustrations, there is none too much room for so large a project, and, for the type of student for which the book is intended, it might have been preferable to give a little more space to some of the larger groups. On the other hand, it may be contended that the book should be used as a reference book as well as, or perhaps rather than, a text-book, and that the inclusion of such groups as 